\title{
Yazılı Basında İmgeler, İkonlar, Mitler ve Deniz'ler
}

\author{
Elif Șeșen ${ }^{1}$ \\ Öz
}

1960’ların öğrenci hareketlerini efsaneleştirme ve liderlerini mitleştirme medyada özellikle 1990'lar sonrası dönemde hızlanmış ve yaygınlaşmıştır. Bu süreçte medyanın değişen mülkiyet yapısıyla artan ticarileşme ve magazinelleşmenin medya içeriklerine yansımasının önemli bir etkisi olduğu söylenebilir. Mitleştirmenin üzerinde en yoğun şekilde işlediği akla gelen ilk isim de 1960’ların öğrenci lideri Deniz Gezmiş'tir. Bu çalışmada, medyanın mitleştirme pratiklerini anlamak amacıyla Deniz Gezmiş'in idamından bugüne 10 yıllık periyotlar halinde 8 gazetedeki haber ve köşe yazıları Mitchell'in imge/imaj soyağacındaki 5 imgeye göre incelenmiştir. Haber ve köşe yazıları, yazılarda kullanılan metaforlar çözümlenerek mitleştirmenin yöntem ve stratejileri ortaya konulmaya çalışılmıştır.

Anahtar Kelimeler: Mit, Mitleştirme, İkon, İmge, Deniz Gezmiş

\section{Images, Icons, Myths and Deniz's in the Written Press}

\begin{abstract}
Mythicizing the student movement and the leaders of the 1960s in the media has increased and widespread, especially after 1990s. It is possible to say that reflection of the increasing commercialization and magazinization of the media depending on the changing ownership structures to the media contents has a significant impact on this situation. Deniz Gezmiş who is the student movement leader of the 1960s' is one of names that come to mind first and has been exposed to mythicizing the most. In this study, the news and the columns in 8 newspapers were examined in 10-year periods from the date of the execution of Deniz Gezmiş according to the Mitchell's images family tree in order to understand the mythicizing practices of the news media. The mythicizing methods and strategies were tried to be explained through analysis of the news and columns and the metaphors passing in them.
\end{abstract}

Keywords: Myth, Mythicizing, İcon, İmage, Deniz Gezmiş

1 Yrd. Doç. Dr., Niğde Üniversitesi, İletişim Fakültesi, Halkla İlişkiler ve Reklamcılık Bölümü 


\section{Giriș}

$\mathrm{M}$ iti, bir kişi, yer ya da olay hakkında o kültürün üyelerinin genel olarak paylaştığı popüler düşünce ya da hikaye olarak tanımlayabiliriz. Mit yaratma süreci ise insanlık tarihinin başlangıcına kadar götürülebilir. Ancak önce yazı, sonra matbaa ve sonra da gazete, radyo, televizyonla gelişen kitle iletişimi mitlerin coğrafi sınırlarını ortadan kaldırarak çeşitli kültürlere ve toplumlara yayılmasını kolaylaştırmıştır. Miti “yaşayan bir gerçeklik" olarak tanımlayan Mircea Eliade (2001:119) en eski, dramatik, hatta, kimi zaman acıklı olan bu öykünün sadece bilinmesinin yeterli olmadığını sürekli olarak anımsanması ve yeniden üretilmesinin gerektiğini söylemektedir. Bu yeniden üretim sürecinde kitle iletişim araçları ya da kısaca medya başrol oyuncularından biridir. Medya, kendi üslubu ile harmanlayarak olayları, yerleri, kişileri mitleştirirken o "şey"in kimi öğelerini abartır kimi öğelerini değersizleştirir kimi öğelerini anlamsız ya da tanınmaz hale getirir. Bundan bugünkü insanlar kadar geçmiştekiler de kaçamaz. Tarih yaprakları üzerindeki tozları silkeleyip daha ilgi çekici, daha etkileyici yani daha çok "satan" hikayeler yazar medya. Bu hikayelerin üzerindeki tozlar ise altın yaldızlıdır çoğu zaman. Medyanın büyülü tozu insanların üzerine serpilince ya kahraman olur ya da düşman. Her iki durumda da gerçekler mitlere karışır. Mitleştirmenin temeli, kahraman yaratmadır. Hemen herkes ya da her konu mitleştirilebilir. Çevre, emek, üretim, barış, demokrasi, hak, suç ve ceza gibi toplumsal konular ya da bu konularla ilgili akla gelen insanlar mitleştirilebilir.

Ülkemizde mitleştirmeye konu olan başlıklardan biri de 1968'in öğrenci hareketleri ve liderleridir. 1960'ların öğrenci hareketlerini mitleştirme ve liderlerini ikonlaştırma, özellikle 1980 sonrası kuşağın öğrenci hareketlerini anlamlandırma ve medyanın temsil pratiklerinde dikkat çekici bir öğe olarak karşımıza çıkmaktadır. Medyanın değişen mülkiyet yapısıyla artan ticarileşme ve magazinelleşmenin medya içeriklerine yansıdığı 1990 sonrası dönemde ise şahikaya ulaşmış görünmektedir. Öğrenci hareketleri bağlamında mitleştirmenin en yoğun işlediği figür ise hiç kuşkusuz Deniz Gezmiş’tir. Bu çalışma da medyada mitleştirmeyi Gezmiş üzerinden örneklendirerek anlamaya çalışan nitel bir çözümlemedir.

\section{İkon, İmge, Mit ve Mitleștirme}

Mitler ve ikonlar, birer anlatı/söylence olarak tüm toplumlarda var olagelmişlerdir. Mit, Yunanca "söz/konuşma" ya da "hikâye" anlamındaki mythos kelimesinden gelir. Mit, toplumsal olarak güçlü, geleneksel bir hikâyedir. Bir hikâyedir, zira bir dizi olayı bir anlatım sırasına koyar; gelenekseldir, zira kuşaktan kuşağa aktarılır; toplumsal olarak güçlüdür, zira mitler sosyal grupların ve toplulukların değerlerini taşır (March, 2014:20). Mircea Eliade (2001:27) miti, "her zaman için bir şeyin nasıl yaratıldığını, nasıl var olmaya başladığını anlatan yaratılış'ın öyküsü” olarak tasvir eder. Bir başka deyişle, mit yaratmak (mitleştirme), bir öykü anlatmaktır. Ancak mit, abartılı öğelerle süslenmiş, cilalanmış ve kutsallaştırılmış bir öyküdür. Fiske'ye (1996: 118) göre de mit; bir kültürün, gerçekliğin ya da doğanın bazı görünümlerini açıklamasını sağlayan bir öyküdür. İlkel mitler; yaşam ve ölüm, insan ve tanrılar, iyi ve kötü hakkındayken çağdaş toplumun sofistike mitleri ise erillik ve dişilik, aile, kahramanlık, başarı ve bilim hakkındadır. 
Honko (1984:137-138) ve mitlere ilişkin teorileri 11 başlık altında sınıflandırır:

- Bilişsel kategorilerin kaynağı olarak Mit

- Sembolik yorumların bir formu olarak Mit

- Bilinçaltının bir izdüşümü olarak Mit

- Insanın hayata adaptasyonunu sağlayan bir faktör olarak Mit

- Davranış kalıbı olarak Mit

- Sosyal yapının meşrulaşması olarak Mit

- Sosyal ilgilerin belirleyicisi olarak Mit

- Kültürel ve sosyal yapının aynası olarak Mit

- Tarihsel durumun bir sonucu olarak Mit

- Dini iletişim olarak Mit

- Yapı için araç olarak Mit

Burada yapı için araç olarak mit yaklaşımına göre mitler; yapılardır, dil ve paradigmatik açıdan tahlil edilirler. Örneğin Claude Lévi-Strauss'a (2013:11) göre mitler bir bütün olarak ele alınması gereken dilsel yapılardır. Bu çalışmada da mitler, metinsel bir yapı olarak ele alınmış ve dilsel pratikler içinden tahlil edilmiştir.

Yunanca bir kelime olan eikon'dan gelen ikon (Latince imago'dan gelir) ise imge/ imaj anlamına gelir. İmge kişinin zihninde oluşan bir fikir, bir izlenim anlamında kullanılmaktadır. İnsan zihninde beliren ya da kurulan görsel anlamlar olarak imgeler "yazınsal kullanımda daha spesifik olarak, zihinde dille yaratılan imge düzenine (imagery) gönderme yapar; dilin sözcükleri ya da sözleri, ya fiziksel algılamaları üretebilecek deneyimlere gönderme yapar, ya da duyu izlenimlerinin kendilerine." (Freidman, 2004:80).

Pierce (1958:157) ikonu; nesnesini temelde benzerliği ile temsil edebilen bir gösterge olarak tanımlar. İkon, daha geniş bir kümede, bir imge, bir göstergedir. Kişiler ya da şeyler bir ikona dönüştürülerek mitleştirilir. Yani mitleştirme ikonlaştırma ile mümkündür ya da mitin temelinde ikon bulunur. Günümüzde ikonu daha çok mitleştirilen kişi anlamında kullanırız; ancak gerçekte ne günümüzün yaratılan modern ikonları vardır ne onların mitleştirilen yaşam tarzları. Mitin mekanizmasının alışıımış temsil biçimlerinin gündelik nesne ve pratiklerle iç içe geçmesine yol açtığını söyleyen Ellis ve Coward'a (1985:56) göre sonunda mitleştirilen ideolojik anlamlar, o nesne ya da pratiğin doğal, sağduyu düzeyindeki gerçekliği gibi anlaşılmaya başlanır.

Günümüzün mitleri; ikonik imaj, algı ve özellikler yaratılarak oluşturulmaktadır. Barthes'a göre mitler politikadan arınmış izlenimi veren sözlerdir. Diğer bir deyişle, okunduklarında veya mitleştirme yolu ile kurulan belli ritüellere katılındığında politik olan gözlerden silinir ve anlamlar doğallaşır (İnal, 2003:18). Mitchell (2005:38) da ikon/imgeleri, "herhangi bir zihni resim olarak değil; tersine soyut, genel, ruhani benzerlik olarak, bizimle yorulmaksızın konuşan yorumcular" olarak görür. Eğer mitlerin üzerimizde sahip oldukları güce nasıl ulaştıklarını anlayabilirsek, onları üreten tasavvuru da anlayabiliriz. Hooke'a (1963:11) göre ise mit, belirli bir durumun meydana çıkardığı insanın hayal gücünün bir ürünü ve bir şey yapma niyetidir ve bu nedenle mit için sorulacak doğru soru aslında "onun gerçek olup olmadığı" değil; "onunla ne yapmak niyetinde olunduğu"dur. Günümüzde, medya mit yaratma sürecinde etkili olduğu gibi yaratılan mitlerin hangi niyetle nerede kullanılacağına da yön vermektedir. Bazen 
siyasal bir ikon yaratılıp etrafında mitler oluşturulurken başarı iktidar ya da oy sayısı ile ölçülmekte, bazen de bir moda ikonu yaratılarak başarı artan satış rakamlarına eşitlenmektedir.

\section{Medyada Mitleștirme ve Deniz Gezmiș}

Mit; bir kavram ya da fikir değil, bir mesajdır ve her şey mit olabilir; yeter ki, bir söylemi olsun (Barthes, 1998:9). Bugün bu söylemi kuran da besleyen de medyadır. Mitleştirme; kişilerin arzu, değer ve algıları tarafından yönlendirilen davranışların yaratılması sürecidir. Ancak, genelde kişi tarafından değil, mitin hikayesini "ambalajlayan" kültür endüstrileri ve medya tarafından şekillendirilir (Kniazeva ve Belk, 2010). Mit bir anlamda kendini tekrarlayarak yaşar, unsurlar sürekli bir araya getirilir (Levi-Strauss, 2013:27). Giddens (2005:18) modern devletlerde ikonların ve sembollerin denetim altında tutulduğunu, sistemin kendisine direnen bir odağın sembolünü baskı ve tasfiye ile ortadan kaldırmaya çalıştığını; ancak, postmodern toplumlarda buna intiyaç kalmadığını söylemektedir. Çünkü, direniş odaklarının çökertildiği, direnişin de ancak ve ancak sermaye sahipliği ile mümkün olduğu bu yapılanmada direniş sembolleri veya ikonları, artık sisteme zarar veremeyen silik ve gerçeküstü kavramlara dönüş(türül) müştür. Muhalif bir öğe, ikonlaşırken muhalif niteliklerini kaybeder, silikleşir, aksi halde, zaten mitleşemez. Ancak, mitleşebilmesi için başta kitle iletişim araçları olmak üzere Althusser'in adlandırmasıyla devletin ideolojik aygıtlarının desteğine intiyaç duyar. Bu bir anlamda karşılıkı işleyen bir süreçtir. Mite dönüşmek için içi boşaltılır, içi boşaldıkça daha çok mitleşir. Medya, kişileri mitleştirirken de gerçekliği bozarak bize sunar. İstediği özelliği alır, istediğini dışarıda bırakır, istediğini büker, istediğini de ötekileştirir.

Hal Foster (2008:131) 'Kültürel Direniş' başlıklı yazısında burjuva kültür pratiğinin, başka sosyal grupların anlamlandırma biçimlerinin temellük edilmesine dayandığını belirtir. Burjuvazi, 'öteki'nin söylemini aşırıp farklı bir bağlama, bambaşka bir yere taşıyarak, yıkıcı olabilen bir söylemi bir tür evcilleştirme işleminden geçirir ve neticede bir tüketim nesnesi olarak dolaşıma sokabilir. Barthes'a (1998:53-54) göre bu ele geçirmenin iki özelliği vardır: birincisi, ötekinin zararsız hâle getirilerek özümsenmesi; diğeri ise ötekinin temsil yoluyla cisimleştirilmesi; ki, burada temsil, etkin varlığın yerine geçer. Bu temellük etme işleminde, bir toplumsal gruba ait özgül bir içerik ya da anlam, soyutlama aracılığıyla, başka bir toplumsal grubun genel kültürel üslubuna dönüştürülür. Barthes (2011:197) bu işleme 'mitleştirme' adını verir ve mitin her zaman dilin çalınması olduğunu, "aşırılıp" başka bir yere farklı ya da eksik bir anlama gelecek şekilde yeniden yerleştirildiğini ve anlamı "biçime" dönüştürdüğünü yazmaktadır. Anlamı biçime dönüştürme, yani bir bakıma soyutu somuta indirgeme, bir tüketim nesnesine dönüştürme pratiği insanlar üzerinden de yürütülür. Yani insan, daha doğrusu o kişinin imajı da alınıp satılabilir bir tüketim nesnesi haline gelir. Kişilerin ikonlaştırılarak mitleştirilmesinin temel alanı haline gelen medyadaki mitik kahramanı sahiplenen grup, bütün iyi özellikleri kahramana atfederken, karşıt gruplar içinse tersi şekilde işleyen bir süreç ortaya çıkar.

Medya, olayları kişi hikayelerine indirgenken bu kişiler arasından bazılarını seçerek öne çıkarır. Kişilerin kimi özelliklerinin abartılarak mitleştirilmesi ile yaratılan figür, özel olarak kurgulanmış bir ikondur. Daniel Cohn-Bendit, Rudi Dutschke, Tarık Ali gibi 1968'in öğrenci liderlerinin yıldızlaştırılmasında kendi kişiliklerinden çok basın etkili olmuştur (Fremon, 2003:37). Haberlerde cesur sözlerine, dramatik öğelerle süslenmiş 
hayat hikayelerine yer verilerek mitik kahramanlara dönüşmelerine ön ayak olunmuştur. Kişiselleştirme bir yandan dile getirilmeye çalışılan toplumsal sorunların buzdağının su altındaki bölümlerini saklamaya hizmet ederken, bir yandan da anlattığı kişisel hikâyeler ile kişilerin mitleştirilmesine ve giderek artan şekilde ticarileşen medyanın magazinelleşmesi ile ortaya çıkan medyatik kahramanlar ihtiyacının giderilmesine yardımcı olur. Bir "öykü" anlatma olarak haberin kalbinde, kişi hikayeleri bulunur ve kişiselleştirme, haberin temelidir. Gitlin (1980:153-154) medyanın öğrenci eylemlerinin altında yatan nedenleri kişiselleştirmeye yönelik söyleminin yanı sıra bir toplumsal hareketin liderlerini resmi kişilikler olarak sergileme eğilimine dikkat çeker. SDS (Student for Democratic Society) örneğinde öğrenci hareketleri ile medya ilişkisini ele aldığı "The Whole World Watching" adlı çalışmasında öğrenci hareketlerinin basın yoluyla simgesel kişilikler ürettiklerini söyleyen Gitlin "Lider, nasıl ünlü bir kişiliğe dönüşür?" sorusuna "Büyük oranda haber yazma sisteminin dramatik kişilik araştırmalarının sonucu olarak" diye cevap verir. Medyanın nesnellik kodları gereği iki tarafa da söz vermiş gibi görünmek için "konuşan" kişilere ihtiyacı vardır. Eylemler pek çok kişiyi tanınır hale getirebilir; ama, medya, içlerinden daha konuşkan ve dramatik bulduklarını ünlü yapar, ancak, istediği özellikleri öne çıkarıp istediklerini saklayarak.

Ülkemizde de benzer bir süreç Deniz Gezmiş için işletilmiştir ve aslında hala işletilmektedir. Haziran 1968'deki İstanbul Üniversitesi (iÜ) işgalinden sonra öğrenci eylemleri içinde etkinliği ve haberlerdeki ağırlığı giderek artan Deniz Gezmiş, ilk kez 31 Mayıs 1969'da iÜ Hukuk Fakültesi öğrencilerinin, reform tasarısının gerçekleşmemesini protesto için giriştikleri işgale liderlik eder. 1 Eylül 1969 tarihinde "üniversiteyi işgal" ettiği gerekçesiyle Hukuk Fakültesi'nden ihraç edilir. Hakkında tutuklama kararının olduğu bu dönemde gazetecilere gizlendiği yerden demeçler verir (Feyizoğlu, 2004:294). 1970'den sonra öğrenci eylemlerinden uzaklaşan Gezmiş, Sinan Cemgil ve Hüseyin İnan'la birlikte Türkiye Halk Kurtuluş Ordusu'nu (THKO) kurar. Daha sonra İş Bankası Emek Şubesi soygunu ve 4 ABD'li askerin Balgat'taki Tuslog Tesisleri'nden kaçırılması gibi eylemler gerçekleştirir. Deniz Gezmiş ve arkadaşları 16 Temmuz 1971'de başlayan THKO-1 Davası'nda TCK'nin 146. maddesini ihlal ettikleri gerekçesiyle, 9 Ekim 1971 'de idam cezasına çarptırılır. Yusuf Aslan ve Hüseyin İnan ile birlikte 6 Mayıs 1972 tarihinde Ankara Merkez Kapalı Cezaevi'nde asılarak idam edilir.

Ülkemizde romanlara konu olan, hakkında şarkılar, şiirler yazılan Deniz Gezmiş, idolleştirilerek mitleştirilen öğrenci liderlerinin akla gelen en tipik örneğidir. Ancak, Gezmiş'in asıl ikonlaştırılması yaşadığı dönemde değil; her alanda gerçekliğinden kopartılan ikonların gazete sayfalarını ve ekranları kapladığı 1980'ler sonrasında olmuştur. 1980'lerle birlikte küreselleşme cereyanından ve popüler ikon patlamasından payını alan Türkiye'de ideolojik hegemonyanın iki önemli kurumu olan medya ve üniversitenin yeniden yapılandırıldığına dikkati çeken Adaklı (2001:246) büyük sermaye yatırımları ile medya sektörünün tekelci düzenin ekonomik ve politik çıkarlarına hizmete koşulduğunu, kamu perspektifini yitiren üniversitelerin de neoliberal politikaların destek ünitelerine dönüştüğünü söylemektedir. ABD'de Reagan, İngiltere'de Thatcher ve Türkiye'de Özal gibi politikacıların uyguladığı ekonomide neoliberalizme, siyasette yeni sağa yaslanan bu hegemonik kültür her alanda ikonlara ihtiyaç duyuyordu. İş ve politika dünyasının ileri gelenleri, kişisel başarı hikayeleri ile medyada sık sık boy göstermeye başlamıştı. Magazin söyleminin; dramatik ve sansasyonel öğeleri öne çıkaran tarih dışı anlatımı, mit/kahraman yaratmaya dönük yapısı haberlere hakim olmaya başlamıştı. Gerçek olay ve karakterlere dayalı olan haber metinlerinde dahi 
gerçeklik yeniden kurulurken; anlatı, iki karşıt gücün çatışması etrafında örülürken bir kişi ya da tarafın mitleştirilmesinin de yolu açılır. Deniz Gezmiş'in de insan dahil her şeyi eşyalaştıran pop çağının ikonik kahramanlarından biri haline getirilmesinde medyada giderek artan magazinelleşmenin yansımalarını bulmak mümkündür.

\section{Mitleștirmenin İmgesel Çözümlemesi}

Deniz Gezmiş'in nasıl bir medya ikonuna dönüştürüldüğünü tarihsel duraklarıyla anlayabilmek için 1972'den günümüze 10 yıllık dilimler halinde 8 gazetedeki haber ve köșe yazıları William T. Mitchell'in imaj/imge soyağacındaki temel imgelere göre incelenmiştir.

İkon/imge teriminin evrensel bir tanımına odaklanmak yerine, imajların kendilerini farklı kurumsal söylemler arasındaki sınırlar temelinde birbirlerinden farklılaştıkları yerlere bakarak işe koyulmak gerektiğini vurgulayan (Mitchell, 2005:13),, bu şekilde analiz için bir imaj/imge soyağacı ortaya koyulabileceğini ifade eder. Ona göre imgeler; dünyaya açılan saydam bir pencere sunmak yerine, temsilin belirsiz, tahrif edici, keyfi mekanizmasını, yani ideolojik mistifikasyon sürecini gizleyen doğallığın ve şeffaflığın aldatıcı görünüşünü sunan bir gösterge türü (Mitchell, 2005:11) sayılmalıdır. Algıladığımız, öğrendiğimiz ya da kavramlaştırdığımız nesne veya oluşların zihinde yerleşen sembolleri olan imgeler (Burnett, 2012:53) görülenin meşruluğunu inşa etmek ve sürdürmekte bir payanda gibidir. İnsanlar zihinlerindeki imgeler ve dillerindeki sözcüklerle konuşurlar. İmgeler yalıtılmış ifadeler değildir; aksine sürekli değişirler, yeniden üretilirler. Mitchell (2005:34) çözümlemesinde, bir ikon/imgenin diğer söylemler arasında nasıl farklılaştırıldığının anlaşııması için yapılması gerektiğine işaret ederek çözümleme için grafik, optik, algısal, zihinsel ve sözel olmak üzere 5 imge belirler. Grafik ve optik imgelerde; ikonun resim, heykel, görüntü gibi görsel özelliklerine bakılır. Algısal imge duyusal verilerden elde edilen dış görünüşe dair özellikleri; zihinsel imge ise ifade edilen düşünceler, anlatılan hatıralar ve inşa edilen fantazileri kapsar. Fantazi burada, Zizek'in (2002:135) ideolojinin işleyişinde hayati öneme sahip olduğunu söylediği dünyayı anlamlı ve tutarlı olarak deneyimleyebilmek için arzularımızın koordinatlarını sunan, bir şeyi arzulamamızı sağlayan çerçeve, olarak tanımladığı kavramsallaştırmaya denk düşmektedir. Toplumsalın bir parçası olan fantazi, gerçekten kaçış için yeni bir gerçeklik inşası, imgesel bir senaryodur. Sözel boyutta ise imgeler, metafor ve tasvirler yoluyla inşa edilir. Aşağıda verilen bu soyağacındaki her bir kol farklı bir entelektüel düşünce disiplininin merkezindeki imge türüne karşılık gelir.

İmaj/İmge Soyağacı (Mitchell,2005:13)

Benzerlik

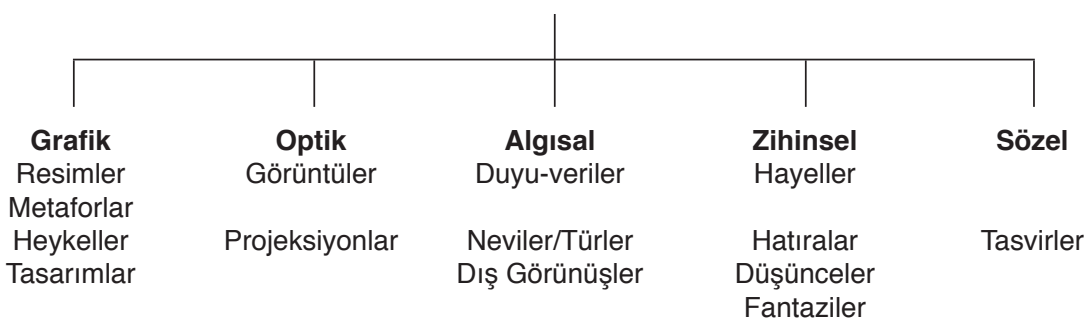


İmgesel bir çözümleme perspektifiyle 68'in öğrenci lideri Deniz Gezmiş örneği üzerinden yazılı basında mitleştirmeye dair nitel bir çözümleme ortaya koymayı amaçlayan bu çalışma kapsamında Cumhuriyet, Evrensel, Hürriyet, Milliyet, Sabah, Tercüman, Türkiye ve Zaman olmak üzere toplam 8 gazetedeki 72 haber ile 19 köşe yazısı incelenmiştir.

İncelenen haberlerin 34'ü Cumhuriyet, 17'si Evrensel, 4'ü Hürriyet, 6'sı Milliyet, 3'ü Sabah, 5'i Tercüman, 1'i Türkiye ve 2'si de Zaman gazetesinde yayımlanmıştır. İncelenen köşe yazılarının ise 3'er tanesi Cumhuriyet, Evrensel, Hürriyet ve Milliyet; 2'şer tanesi Tercüman, Türkiye ve Zaman, 1 tanesi de Sabah gazetesinde yayımlanmıştır.

Seçim yaparken, gazeteler arasında karşılaştırma imkan sunması açısından politikideolojik yönelimleri farklı olanlar tercih edilmiştir. Örneklemi oluşturan gazeteler politik-ideolojik spektrum üzerinde "sağ", "merkez" ve "sol" olmak üzere üç gruba ayrılmış, popüler basını temsil eden Hürriyet, Milliyet ve Sabah spektrumun merkezine yerleştirilmiştir. Sosyal demokrat yönelimli Cumhuriyet ile Evrensel ise spektrumun soluna konumlandırılmıştır. Spektrumun sağı ise Tercüman, Türkiye ve Zaman olmak üzere 3 gazete ile temsil edilmiştir.

Çalışmada ele alınan dönemin çok geniş bir periyodu kapsaması bir takım sınırlandırmalara başvurulmasına neden olmuştur. Tarihsel olarak araştırma için Deniz Gezmiş ve arkadaşlarının idamının infaz edildiği 6 Mayıs 1972 tarihi dikkate alınarak her on yılda bir idamların yıldönümünün 2 gün öncesi ile 3 gün sonrasında yayımlanan haber metinleri ve köşe yazıları incelenmiştir. Gezmiş ve arkadaşlarının idamlarının gerçekleştiği 1972 yılında Evrensel, Sabah, Türkiye ve Zaman gazeteleri henüz yayın hayatında olmadıkları için idamlarla ilgili haberlerine yer verilememiştir. 1982 yılındaki haberlerde de aynı sebeple Sabah ve Zaman gazetelerine, 1982 ve 1992 yılındaki haberlerde de Evrensel gazetesine yer verilememiştir.

\section{Haber ve Köșe Yazılarında Deniz Gezmiș}

Deniz Gezmiş'in arkadaşları ile beraber idamı ile ilgili haber ve köşe yazıları sözel, zihinsel, algısal ve grafik olmak üzere imge soyağacının 4 dalı etrafında analiz edilecektir. Analiz yazılı basını kapsadığı için görüntüler ve projeksiyonlardan oluşan optik imgeye yer verilmeyecektir. Grafik imgenin alt başlıklarından da sadece fotoğraflara (fotoğraflı haberlerde) dair değerlendirme yapılabilecektir.

Çalışma yazılı basındaki haberler ve köşe yazılarını kapsadığı için sözel imge ile zihinsel imge analizde daha büyük ağırlığa sahiptir. Sözel imgenin her dilin kilit taşı olduğunu ifade eden Mitchell (2005:31) metafor ve tasvirlerin "sözel ifadelerden kaynaklanan" imajları bizatihi "nesnelerden akan imajlardan" çok daha canlı bir şekilde ürettiğine işaret etmektedir. Analize de sözel imgelerden başlanacaktır.

\section{Sözel İmge}

Deniz Gezmiş'ten haberlerde ilk defa Haziran 1968'de "Rektör makam odasında kapıya doğru yürüyerek öğrencilerin önderliğini yaptığı sanılan, adının Deniz Gezmiş olduğu öğrenilen öğrenciye hitaben 'hoş geldiniz, buyurun' demiştir” (Cumhuriyet/14.06.1968) şeklinde bahsedilmektedir. 
Gezmiş ve arkadaşlarının idamları ise 7 Mayıs 1972 tarihli Cumhuriyet gazetesinde "İdam edilen Gezmiş, Aslan ve İnan gömüldü" başlığı ve büyük harflerle "Hükümlüler dini telkin yapılmasını reddettiler" alt spotu ile; Hürriyet gazetesinde "Idam edildiler" başlığı ve "Dini telkin istemediler" alt spotu ile; Milliyet gazetesinde büyük puntolarla "Gezmiş, Aslan ve İnan idam edildi" başlığı ve "Yenimahalle'ye gömüldüler" alt spotu ile; Tercüman gazetesinde ise "Idamdan önce dini telkin istemediler" manşeti ve "Anarşistler infaz sırasında 'Yaşasın marksizm, kahrolsun faşizm' diye bağırdılar" alt spotu ile verilmiştir.

Sözel imgenin iki temel yolu tasvirler ve metaforlardır. Mitleştirme sürecinin ilk adımlarından sayılabilecek Uğur Mumcu'nun idamlardan 10 yıl sonraki "Sesleniş" başlıklı köşe yazısında (Cumhuriyet/07.05.1982)

Dağ gibi karayağız birer delikanlıydık. Yaşamımızın en güzel yıllarını, birer taze çiçek gibi verdik topluma. Yabancı petrol şirketlerine karşı devletimizi savunduk; komünist dediler. Ülkemiz bağımsız değil dedik; kelepçeyle geldiler üstümüze. Bir gece sabaha karşı, pranga vurulmuş ellerimiz ve ayaklarımızla çıkarıldık idam sehpalarına. Mezar toprağı gibi taptaze, mezar taşı gibi dimdik boynumuzu uzattık yağlı kementlere. Asııdık ey halkım, unutma bizi...

sözleriyle tasvir edilen Gezmiş ve arkadaşlarıdır.

Köşe yazıları ve haberlerde üç idamı da kapsayan "Deniz’ler” şeklinde çoğul bir kullanım söz konusudur. "Denizler" hem idam edilen diğer 2 kişiyi de kapsayacak anlamda hem de o dönemde ve sonrasında Gezmiş'in fikirlerini destekleyenleri de işaret edecek şekilde kullanılarak metonimi (düzdeğişmece) yapılmaktadır. Bir bütüne parçasıyla gönderme yapma anlamına gelen metonimi çağrışımlara dayalı bir anlam inşasıdır. Metoniminin temel olarak, bir parçanın bütünü temsil edecek şekilde kullanılmasını sağlamaktır. Yani gerçekliğin bir parçasını, bütünü temsil etmesi için seçeriz. Gerçekliğin bilinmeyen geri kalanını da bu seçimden yola çıkarak inşa ederiz (Fiske, 1996:128). Diğer örnekler ise Cumhuriyet gazetesinde "Deniz'leri kurtarmak istediler (08.05.2002/6.sayfa)", “Deniz’ler Anılıyor (06.05.2012/1.sayfa)"; Hürriyet gazetesinde "Deniz’ler Mitinglerle Anılıyor (06.05.2012/2.sayfa)" ve Evrensel gazetesinde "Her birimiz Deniz'ler gibi (06.05.2002/2.sayfa)", “Deniz'ler Her Yerde Anılıyor (06.05.2002/3.sayfa)", "Deniz'lerin Yolunda (07.05.2002/1.sayfa)", "Deniz'lerce Çoğalarak (07.05.2012/1.sayfa)", "Bu hack Deniz'ler için (07.05.2012/7.sayfa)" şeklindedir.

Haberlerde ayrıca "bizim çocuklar" (Cumhuriyet, Evrensel) şeklinde sahiplenme, aileden biriymişçesine bahsetme, yakınlığı gösteren bir ifade tarzı olarak dikkat çekmektedir. Burada sahiplenmenin mitleştirmeyi de kolaylaştırdığını söylemek yanlış olmayacaktır. Sahiplenmenin bir diğer örneğinde, 6 Mayıs 1992 tarihli Cumhuriyet gazetesinin ilk sayfasındaki "Aşk olsun sana çocuk, aşk olsun" başlıklı haberde Can Yücel'in Gezmiş anısına yazdığı ve Latince 'bizim deniz' anlamına gelen Mare Nostrum adlı şiirinden "Acıyorsam sana anam avradım olsun ama aşk olsun sana çocuk. AŞK olsun!" mısralarına yer verilmektedir. Şiire "Deniz Gezmiş'in hatırası" adlı yazısında Mümtaz'er Türköne (Zaman/06.05.2012) de "O yılları kitaplardan ve televizyon dizilerinden öğrenenler için Can Yücel'in mısraları Deniz Gezmiş'in simgeleştirdiği duyguyu çok iyi anlatır." sözleri ile atıfta bulunmaktadır. 
Mitsel kurmacanın en temel metaforlarından biri haberlerde sıkça geçen "fidan" benzetmesidir. Haberlerde 3 gençten "3 fidan" şeklinde bahsedilmektedir. Cumhuriyet gazetesinin 4. sayfasında verilen haberler "Üç fidan unutulmadı (06.05.2002)" ve 5. sayfasında verilen "Üç fidan binlerce kişinin katılımıyla anıldı (06.05.2012)" başlığını taşımaktadır. 6 Mayıs 2002 tarihli Milliyet gazetesinin 17. sayfasındaki haber başlığı "Darağacında 3 fidan karanfillerle anıldı", 06 Mayıs 2012 tarihli Sabah gazetesinin 20. sayfasındaki haber başlığı ise "Üç Fidan, idamlarının 40'ıncı yılında anıldı" şeklindedir. Fidan metaforu, önce Vatan gazetesinde yazı dizisi, sonra da 1976'da kitap olarak basılan ancak uzun yıllar yasaklı kalan; Gezmiş, İnan ve Aslan'ın dışarıda son günlerini ve yakalanışlarını anlatan Nihat Behram'ın belgesel anlatı tarzındaki 'Darağacında Üç Fidan' adlı kitabına bir göndermedir. Metafor (eğretileme) bir kelime ya da deyimin ilk kullanım alanı dışında başka bir alanda kullanılması, herhangi bir şeyin niteliğinin bir gerçeklik düzleminden bir başka düzleme geçerek yer değiştirmesi ve böylece bir başka şeyi açıklamasıdır (Foss, 2004:299). Benzetme ve göstergeler aracılığıyla iki değer veya kategori arasında bağlantı kurarak daha kolay anlaşılabilmelerine imkan tanımakta ve böylece de yaygınlaşmalarını sağlayabilmektedir. Fidan toprağa ekilip güçlendiğinde ağaca dönüşür. Ağacın genç hali olarak düşünülebilecek fidan metaforu; Gezmiş, İnan ve Aslan'ın gençliklerini vurgulamaktadır. Zira idam edildiklerinde Gezmiş 25, Aslan ve İnan 23 yaşındadır. Sökülen fidanların yeşeremeden ölmesi gibi idamlar da üç gencin ve fikirlerinin kök salamadan sökülmesine çağrışım olarak anlamlandırılabilir. Fidan, Mitchell (2005:35) bir düşünceyi, nesneyi ya da kişiyi adını telaffuz etmeksizin temsil eden karakter ya da sembol olarak tanımladığı ideogramın da bir örneğidir. Üç fidan, üç gencin adları anılmadan onları çağrıştırmaktadır.

Metaforik anlatım, haberlerde Gezmiş'in haki yeşili parkası ile ilgili kısımlarda da görülmektedir. Hakkında pek çok hikaye anlatılan, hatta şarkı ${ }^{2}$ yazılan yeşil parka ${ }^{3}$, Hitler'in badem bıyığı, Charlie Chaplin'in melon şapkası ve bastonu ile Süleyman Demirel'in fötr şapkası gibi kişi ile özdeşleş(tiril)miş bir giysi ve mitleştirmenin en önemli öğesi olarak karşımıza çıkmaktadır. Dava sürecinde üç gencin avukatlarından biri olan Halit Çelenk ile yapılan görüşmeye dair Cumhuriyet (07.05.2002/3.sayfa) gazetesinde yayımlanan haberde "evin en değerli hazinesi" olarak tanımlanan parkanın fotoğrafı çekilirken herkesin "ağlamaklı" olduğu ifade edilmektedir. Yazar, parkayı "Türkiye'nin en tanınmış giysilerinden biri. Hemen tanınan ağır bir yeşil ve aslan yelesi gibi bir yaka. Canlı gibi duruyor. Kim bilir kaç kez Deniz'in ellerinin girip çıktığı ceplerde avuç içi izleri var. Fotoğrafı çektikten sonra özenle yerine kaldırılıyor" gibi oldukça duygusal ifadelerle tasvir etmektedir.

Yeşil parka, mitleştirmenin zihinsel imgesinde inşa edilen fantazilerin de bir parçasıdır. Gezmiş'in yakalandığı gün çekilen fotoğrafı ile toplumsal hafızada yer eden yeşil parka aslında daha çok askerlerin kullandığı kapüşonlu, kalın bir tür giysidir. Parkanın rengi olan haki, asker yeşili olarak da bilinir. Askerliğe, savaşa, zor şartlar altında mücadeleye dair çağrışımlar yapar. Fidan gibi aslında parka da yine Mitchell'in (2005:35) adlandırmasıyla bir ideograma dönüşmüş durumdadır. Gezmiş ile özdeşleştirilen

2 Cem Karaca'nın parka adlı şarkısının dizelerinden: “Dedenin üç aylıktan alınmıştı o parka/Kirli yeşil bir renkti eskiceneydi parka/Üst cebi sökülmüştü kullanılmıştı parka/Bir sabah onun sırtında çıktı gitti o parka”

3 Yılmaz Aysan'ın Afişe Çıkmak (2013) adlı kitabında Gezmiş'in arkadaşlarından Hasan Barutçu'nun anlattıklarına dayanılarak, Gezmiş'in parkayı, arandığı için İstanbul'dan Ankara'ya gelip ODTÜ yurdunda saklandığı sırada, 1970 kışında okulda düzenlenen bir maskeli baloda vestiyerden aldığı yani asında kendisine ait olmadığı anlatılmaktadır. 
kapüşonu kürklü, yeşil parkanın aslında, Gezmiş tarafında bir ideolojinin sembolü olarak giyildiğine dair bir bilgi ya da hatıraya rastlanmamaktadır. Ancak Erdal Öz, Gezmiş ile yaptığı görüşmelerde tuttuğu notlardan yola çıkarak yazdığı Gülünün Solduğu Akşam (1987) adlı kitabında Gezmiş'in idamını hayal ettiği bölümlerde "Asılma günü gelip çatınca, o sevdiğim giysilerimi giyeceğim: postallarımı, parkamı." diye anlatır. Anıroman türündeki kitabın hangi bölümlerinin Gezmiș'in sözlerine dayandığı net değildir; ancak, bu bölümlerin tamamen kurmaca olduğu idamın tanıklarından Halit Çelenk'in röportajından anlaşılmaktadır.

Bir nesne bazen bir dünya görüşünün ya da kültürün taşıyıcısı, simgesi olabilir ve o nesneye dair yan anlamsal bir okuma yapılırken, tarihsel ve toplumsal dağarcıktaki yeri, herhangi bir düşünceyi simgeleyip simgelemediğine de bakılır. Düz anlam neyin söylendiği ya da fotoğraflandığı, yan anlam ise nasıl söylendiği ya da fotoğraflandığıdır (Fiske, 1996:117). Yan anlamda gösterge bütün olarak ikinci bir kavramın, yani bir ideolojik kavramın eklemleyicisi olarak belirir (Coward ve Ellis, 1985:55). Bugün popüler kültürün üretim çarkında Che Guevara'nın siyah, yıldızı beresi gibi bir moda imgesi olan yeşil parka Gezmiş̧in idamından sonra devrimci solun nişanesi haline ge(tiri)Imiştir. Yeşil parka giymek, "Ben ideolojik olarak Sol ${ }^{4}$ görüşlüyüm" demektir.

Bir başka metafor idamların anlatımında görülmektedir. İlhan Selçuk 06.05.1992'deki "20 Yıl Sonra” başlıklı yazısında "Deniz, Yusuf, Hüseyin asıldılar. Yüreğimizde o günden bu yana zamanı anımsatan bir saatin sarkacı gibi sallanıyorlar" diye saat metaforu ile anlatmaktadır idamları. 07.05.2002'deki yazısında ise

6 Mayıs 1972 sabahı idam ipini boyunlarına "Kahrolsun emperyalizm" ve "Yaşasın tam bağımsız Türkiye" diye haykırarak geçiren Deniz'ler siyasal idam zincirinin gencecik halkalarıydı. Sosyalizm mücadelesinin bu coğrafyadaki mihenk taşıydı. Deniz'lerin 1968'lerdeki öfke isyan dolu bakışlarında ve ölümün üzerine yürüyen kararlı, korkusuz, genç yüzlerinde umutlu bir gelecek vardı ve 6 Mayıs 1972 sabahı öldürülen bu gelecek hayaliydi.

şeklindeki sözler ile bir zincirin halkalarına benzetmektedir.

Mitleştirme bazen de çeşitli metafor ve negatif yüklemelerle tersi yönde işletilmekte, değersizleştirme ile bir tür karşı-mitleştirme yapılmaktadır. İdamlar sonrasındaki haberlerde olumsuzlama amacıyla en çok kullanılan metafor "üç anarşist"tir. O günlerde idamların haklı ya da haksızlığının tartışıldığı haberlere pek rastlanmamakta, "Neden bu yanlış yola girdiler anlamaya çalışmak lazım" diyen cılız sesler de şiddetle eleştirilmektedir. Değersizleştirme süreci de tüm ağırlığıyla harekete geçirilmiştir. Örneğin, Tercüman gazetesinde "Deniz Gezmiş ODTÜ'de harem hayatı yaşamış" başlıklı haberin spotu da "20 kızla sevişiyormuş" şeklindedir. Toplumsal ahlaka aykırı davranan, sapkın bir kişilik portresi çizilmektedir. Haberin devamı ise "Gezmiş, konduğu cezaevi hücresinde 25-30 kişiyle kalıyor. Muhtemelen Sinop Cezaevi'ne gönderilecek” şeklindedir.

7 Mayıs 1972 tarihli “Idam yetmez, kök kazımalı” başlıklı yazısının girişini "Defolup

4 Sağ ve sol terimlerinin kökenine dair savlardan birine göre ayrım, 1789'da Genel Zümrelerin ilk toplantısında benimsenen oturma düzenine, Fransız Devrimi'ne kadar gider. Devrim sonrasında "sağ" terimi, gericilik ve kraliyet yanlıığı olarak; "sol" terimi de devrimci veya eşitlikçi duygudaşlığı barındıran terim olarak anlaşılmaya başlanmıştır (Heywood, 2007:21). Ancak bu ayrım 1960'lardan günümüze, devrim yanlısı olmak ya da olmamak arasındaki basit bir tercihin çok ötesindedir. 
gittiler" sözleri ile yapan Rauf Tamer (Tercüman) "Cumhuriyetimize karşı bir savaş açmışlar. Savaşı kazanmak için her türlü silaha başvuracaklar, Cumhuriyet ise kendini savunmak, kısacası, yaşamak için hiçbir silaha başvurmayacak. İnsan haklarının hangi kitabında yazar böyle şey? Lütfen söyler misiniz?" sözleri ile Gezmiş ve arkadaşlarını Cumhuriyet düşmanı olarak etiketlemektedir.

İdamlardan 10 yıl sonra 7 Mayıs 1982'de Nazlı llıcak yine Tercüman gazetesinde "Tarihten bir yaprak" başlığıyla

12 Eylül, Türk milletinin meşru müdafaaya geçtiği gündür. İdamlar bu meşru müdafaanın bir neticesidir. 1972'de Deniz Gezmiș'e, Yusuf Aslan'a, Hüseyin İnan'a Meclis'te oylarıyla sahip çıkanların Kızıldere'de Mahir Çayan ve arkadaşlarının öldürülmesini 'devlet terörü' olarak vasıflandıranların artık sesi soluğu kesilmiştir.

sözleri ile idamları haklılaştırmaktadır. Aradan geçen 10 yılda değersizleştirme stratejisinde pek bir farklılık olmamıştır. Aynı günün Milliyet (07.05.1982) gazetesinin 7. sayfasındaki "Nasıl Asıldılar?" başlıklı haberde de Gezmiş, Aslan ve İnan'ın idamları oldukça resmi bir dille, 3 paragraf halinde kısaca anlatılmakta, eylemleri ise 6 paragraf halinde uzun bir şekilde sayılmaktadır.

Nazlı llıcak için 30 yıl sonra da pek bir şey değişmemiş görünmektedir. Zira Sabah gazetesinde 7 Mayıs 2012 tarihli "6 Mayıs ve İdamlar" başlıklı yazısında

Bugün, ideallerini uygulamak için devrime soyunan gençlerin idam edilmesinin çok yanlış olduğunu rahatıkla söyleyebiliriz. Ama o günkü anarşi ortamında ve idamların olağan karşılandığı bir dünyada, parlamentoda 'evet' oyu kullananlar, sadece 'zamanın ruhunu' yansıtıyorlardı.

sözleri ile neredeyse aynı bakış açısı tekrarlanmaktadır.

07.05.2002 tarihli Türkiye gazetesinde Yavuz Bülent Bâkiler ise "Hem komünist hem de Atatürkçü olunmaz" başlıklı yazısında

Deniz Gezmiş, Yusuf Aslan, Hüseyin İnan 6 Mayıs 1972 tarihinde idam edilen delifişek komünist gençlerimizdi. Dün olduğu gibi bu gün de bu komünist militanlara sahip çıkan, onları alkışlayan, bağırlarına basan kimseler var. Devletimize, milletimize büyük hizmetlerde bulunan eski Bașbakanlarımızdan Adnan Menderes'in ve iki bakan arkadaşının çok adi bir hükümet darbesiyle iktidardan düşürülmelerine ve çok zalim, çok gaddar, çok alçak davranışlarla asılmalarına âdeta alkıș tutan bazıları, Deniz Gezmiş ve iki arkadaşının idamına hâlâ gözyaşı döküp dövünüyorlar.

sözleri ile sanki sözkonusu olan insan hayatı değilmiş gibi idamlar adeta bir terazinin iki tarafına yerleştirilmekte ve bir tarafın ağır bastığı söylenmektedir.

2012 yılına gelindiğindeyse Taha Akyol Hürriyet gazetesindeki 9 Mayıs 2012 tarihli ve "Deniz Gezmiş efsanesi" başlıklı yazısında olayın hukuki ve siyasi olmak üzere iki boyutu olduğundan bahsederek idamlara dair mahkeme kararının hukuken doğru; ancak, Meclis'in kararı onaylamasının siyasi olarak yanlış olduğunu ifade etmektedir. Benzer bir bakış açısı Atilla Yayla'nın "Deniz Gezmiş'in haksız idamı ideolojik idealini meşrulaştırır mı?" başlıklı yazısındaki (Zaman/08.05.2012) 
Deniz Gezmiş ve arkadaşlarının idamı kesinlikle haksız ve gayri adildi. Ancak bu, onların bir dizi eyleminin hiçbir şekilde evrensel hukukta yeri bulunan ve faillerinin cezalandırılmasını gerektiren suçlara bulaşmadığını göstermiyor. Ne yazık ki bu insanlar banka soyma, adam kaçırma, darp, şiddet uygulama ve baskı-şiddet yoluyla eğitimi engelleme gibi suçlardan uzak kalmadılar. Bu suçlara hangi amaçla yöneldikleri onları suç olmaktan çıkarmaz.

sözlerinde dile gelmektedir.

Olumsuzlama ve negatif çağrışım için orak ve çekiç metaforlarına başvurulan Sabah (07.05.1992) gazetesinin 13.sayfasındaki haberin başlığı ise "Deniz Gezmiş orak çekiçli bayrakla anıldı" şeklindedir. Haberde "bölücü bazı sloganlar atıldığı ancak polisin sıkı güvenlik önlemleri almasıyla olay çıkmadığı" belirtilmektedir. Tarihin en politik ve ideolojik sembolleri arasında yer alan orak ve çekiç (Rusça "Serp i Molot"), kendisini komünist olarak tanımlayan politik hareketlerce logo ya da amblem olarak kullanılmaktadır. Köylülerin ve işçilerin birliğini ifade eden orak ve çekiç metaforları komünizmin sembolleri olup Bolşevik Devrimi sonrasında Lenin ve Halk Komiserleri Konseyi tarafından SSCB'nin resmi sembolü olarak kabul edilmiştir. Bolşevik propagandaya hızlıca uyarlanmış ve 1 Mayıs 1919 kutlamalarından sonra yaygınlaşıp, popüler hale gelmiştir. Bugün Çin gibi dünyanın bazı yerlerinde işçi devriminin bir sembolü olarak hala kullanılıyor olsa da büyük çoğunlukla Karl Marx ve Frederick Engels'in devrimci teorilerine sempati duyan insanların giydiği tişörtler, rozetler ve şapkalarda görülür (Piercy, 2014:63). Haberde belirtilen orak-çekiçli bayrak; kızıl propaganda, komünizm, devrim, sağ-sol ve kardeş kavgası, 12 Eylül gibi pek çok olumsuz anlam yüklenen kelimeyi de çağrıştırmaktadır.

\section{Zihinsel İmge}

Zihinsel imgenin altında dönemin tanıklarının ağzından anlatılan hatıralar ile kişisel yorumlar ve fantaziler yer almaktadır. THKO-1 Davası ile ilgili 18 Temmuz 1971 tarihli gazetelerde haberlerde"Bazı suçları kabul eden Gezmiş dünkü duruşmada heyecanlandı, boğazı düğümlendi ve ağladı (Tercüman)", "Gezmiş’in alçak konuşmalarında, hareketlerinde bile sinirli olduğu göründü (Hürriyet)" gibi mahkemedeki durum hakkında kişisel yorumlara yer verilmektedir.

Mitleştirmenin zihinsel imgesel çözümlemesinde asıl önemli rolü, haber ve köşe yazılarında yer verilen hatıralar oynamaktadır. İdamların yıldönümündeki haberlerde 1990 'lı yıllardan sonra hatıralara yer verilmeye başlanmıştır.

1992 yılının haberlerine o günlerde ülke gündeminde tartışılan idam cezasının kaldırılması konusu eklemlenmiştir. Bu bağlamda, Cumhuriyet gazetesinin 06.05.1992 tarihli nüshasının 4. sayfasında yayınlanan "Cinayet için özel kanun çıkmaz" başlıklı haberde, o günkü koalisyon hükümeti Başbakanı Süleyman Demirel'e 20 yıl sonra "Yeniden bir oylama olsa idamları yine onaylar mıydınız?" sorusunun yöneltildiği ve onun da "Bu cevabın artık kimseye yararı yok" diye cevap verdiği anlatımaktadır. Aynı haberde Haberlerde, mahkemenin idamı isteyen savcısı Baki Tuğ'un "Onlar' biz yanlış yaptık deselerdi' idam edilmezlerdi. Ancak bunu sonuna kadar kabul etmediler" dediği ve idamları karara bağlayan emekli hâkim Nahit Saçlığlu'nun da idamların "adli bir hata" olduğunu söylediği ifade edilmektedir. 
2002 yılındaki haberlerde de idam cezasının kaldırılması hala ülke gündemindeki yerini korumaktadır. Bu sefer politik gündem ile bağlantılandırılan nokta ise üç gencin babalarının idam öncesi yazdıkları dilekçe olur. Hürriyet gazetesinde 6 Mayıs 2002 tarihinde 2. sayfada yer alan "Mitinglerle Anılıyor" başlıklı haberde,

...devlet büyüklerine seslerini duyurma mücadelesi veren üç gencin babalarının son bir çırpınışla 'Kanları kaynayan gençliklerinin de etkisi altında işledikleri suçlardan dolayı oğullarımıza reva görülen ölüm cezasının bağışlanmasını diliyoruz' şeklindeki dilekçe ile TBMM'ye başvurduklar ancak Başbakan Nihat Erim'in cevabının artık bir şey yapılamayacağını bildirmek olduğu" anlatılmaktadır.

6 Mayıs 2012 tarihli Hürriyet gazetesinin 2. sayfasında yer alan "Asılmalarının üzerinden 40 yıl geçti” başlıklı haberlerde ise "Devrimci Gençlik Hareketi'nin liderlerinden Deniz Gezmiş ile arkadaşlarının asılarak idam edilmesinin üzerinden 40 yıl geçti. Gezmiş'in arkadaşı avukat İlker Gürkan'a yazdığı mektuplardan bugüne 3 tanesi kaldı. İşte o hazin mektuplar..."

sözleri ile Gezmiş'in daha önce hiçbir yerde yayınlanmadığı belirtilen mektuplarına yer verilmektedir.

Haberlerde hatıralarına başvurulan önemli bir kişi; Gezmiş, Aslan ve İnan'ın avukatları Halit Çelenk'tir. Cumhuriyet gazetesinin 06.05.2002 tarihli "Üç Fidan Unutulmadı" başlıklı 4. sayfada yer verilen haberde;

Daha yaşarken bugünleri görmüşlerdi. Savunmalarında dünyanın tüm ezilen insanlarını, canavarca öldürülenlerin mücadelelerini selamlamışlardı. Yârin yanağından gayrı her şeyin hakça paylaşıldığı bir düzendi istedikleri. Yaşasaydı bağımsızlık ve emperyalizm karşıtı mücadelesini daha kararlı ve örgütlü bir şekilde sürdürür, 1 Mayıs'larda devrimci işçi ve emekçilerin yanında olurdu. Üniversitelerde satırlı ve bıçaklı saldırılara uğrayan öğrencileri savunurdu.

şeklinde avukatları Halit Çelenk'in düşüncelerini yansıtan ifadelere yer verilmektedir.

Can Dündar 07.05.2002 tarihli Milliyet gazetesinde "O adam neden sadece 3 fotoğraf çekti?" başlıklı köşe yazısında Halit Çelenk tarafından "gözyaşları içinde" anlatılan, mahkeme sırasında resmi elbiseli bir kişinin yargılanan 23 kişiden sadece asılan 3 kişinin savunması sırasında salona girerek fotoğraflarını çekip gittiğine dair hatırasını aktarır ve "Demek sonucu belliydi mahkemenin..." şeklinde yorumlar.

Evrensel gazetesinin 07.05.2012 tarihli nüshasında da "Denizler'in avukatı, yoldaşı, son anlarına tanıklık eden" Halit Çelenk ile yapılan röportaja ve hatıralarına yer verilmektedir. İdam, Çelenk'in ağzından

Benim için çok acılı bir geceydi. Düşünebiliyor musunuz yurtseverliğine, ülkesini, halkını sevdiğine inandığınız 3 genç insan... İdamdan sonra eve gelince kendimi balkona atıp uzun süre ağladım. Bir baktım ki çocukların babaları... Ne söyleyeceğinizi bilmiyorsunuz o insanlara. Uzun süre geceleri uyuyamadım ondan sonra. Hep o geceyi düşünüyorum. Deniz ipte sallanıyor. Çocuk silkiyor, silkiyor. Belden aşağısı... Doktora gidip yoklayın diyoruz. Nabız atıyor diyor doktor. Yani hala yaşıyor demek. Düşünebiliyor musunuz, yaşıyor çocuk ve can veremiyor. 
sözleriyle oldukça canlı bir şekilde anlatılmaktadır.

Mitleştirmenin diğer önemli parçaları fantezilerle harmanlanan kişisel düşünce ve yorumlardır. 07.05.2002 tarihli Cumhuriyet gazetesindeki köşesinde İlhan Selçuk

Namuslu, devrimci, heyecanlıydı. Belki hatalar yapmış ama masum yüreğiyle hep çabalamıştı. Gençtiler, bilgili, birikimli ve en önemlisi yurtseverdiler. Arabaları, yatları, katları olmadı ama idealleri vardı. Bu idealleri de tam bağımsız Türkiye idi. Demokrasi ve adalet için savaştılar.

diye anlatırken, Rahim Er (Türkiye) 08.05.2012 tarihli "Onlar hain mi, kahraman mı?" başlıklı yazısında da

Deniz Gezmiş, Yusuf Aslan ve Hüseyin İnan... Üç genç adam... İdamlarının üzerinden kırk yıl geçmiş. Fakat o görüntü sanki dün gibi. Deniz Gezmiş, İstanbul Üniversitesinde iç kapının önünde yüksek bir yere çıkmış konuşmakta. Kızlı-oğlanlı 10-15 kişi kendisini dinliyorlar. Sağı ve soluyla bu gençler, nesillerinin en zekileriydi. Türkiye geri kalmıştı. Geri kalmışlık hazmedilemiyordu. Aslında şuur altlarında bir imparatorluğun kaybına duyulan öfke yatmaktaydı. Hepsi de kendi açısından samimiydi. Kurşunun üzerine gitmenin, idam sehpasına çıkmanın riyakârlığı olur mu?

sözleri ile tasvir edilirken "Bora Gezmiş ile de sık sık konuşurduk bu konuyu. Onlar davaları uğruna can verdiler" sözleri ile hatıraların da eklendiği kișisel düşüncelere dayanan yorum ve değerlendirmeler yapılmaktadır. Ayrıca "Onlar için dün kurşunlar, urganlar konuştu. Bugün romantizm konuşmakta" şeklinde devam eden köşe yazısı idamlar sonrasındaki romantikleşme ve kahramanlaştırmaya dikkat çekmektedir.

Ece Temelkuran "Siz de bir dilim Deniz Gezmiş alır mıydınız?" (Milliyet/06.05.2002) başlıklı köşe yazısında o günlerde bir TV dramasında bir polisi oynayan Mehmet Ali Alabora'nın Deniz Gezmiş kılığına girmesini "muhalefetin zararsızlaştırıldıktan sonra gösteriye dahil edilmesi” olarak okuyarak eleştirmektedir. Ona göre, mitleştirme ancak muhalifin adı manasızlaştırıldıktan sonra mümkündür.

Diğer ikisi yeterince yakışıklı bulunmadığı için herhalde 'politik züccaciyeciler' yüzünü kahve fincanlarına basar, 'heyecanlı tekstilciler' fotoğrafını t-shirt'lerin üzerine mıhlar. Memoli, Deniz Gezmiş'i anmak için 'kılığına' girince bu 'şirin' bir şey olur. Çünkü böylece Gezmiş̧i anma 'afacanlığı' sistemin rızasını almış olur, 'gösterinin' iltifatını kazanmış olur ölü çocuklar.

sözleri ile medyanın her şeyi -üç gencin idamı gibi dramatik bir konuyu dahimagazin sisinin arkasına gizleyebildiğine işaret etmektedir. Her şeye bir "neo" ya da "post" takısının getirildiği ve yeninin sürekli vurgulandığı "yeni" dünyada, mitleştirilen kişi ya da şeyler bir yandan içi boş birer imaja/ikona dönüştürülürken bir yandan da ötekileştirilmektedir (Fiske ,1996:152). Gösteri, çağımızın toplum ve medya hayatında ağırlığını giderek artırmaktadır. Guy Debord (2006:31) artık birer "gösteri toplumu" haline gelmiş günümüz toplumlarında, insanların bilinçlerinin de nesnel gerçeklikten yoksun ikonik bilince dönüştüğünü, nesnelerin imajlarının onların yerine ikame olduğunu belirterek "Gösteri metası, tamamen normal şeyleri -bir araba, ayakkabı, sosyoloji doktorası hatta bir insan- olağanüstü metalar gibi, üstün ve belki de elitist bir varoluşun anahtarı gibi sunmaktadır" demektedir. Kellner (2011:46) de ünlüleri 
"medya tarafından beslenip büyütülen ve kutsanan kitle idolleri” olarak tanımlarken ünlüleri medyanın ürettiğini, haber ve bilginin artan oranda bir 'medya gösterisi' olarak işletildiğini söylemektedir.

Mümtaz'er Türköne (Zaman/06.05.2012) de Gezmiş ile ilgili hatıraların magazin maksatı kullanımını eleştirerek

Bülent Ersoy'un kulağına taktığı küpelerle gündeme gelmesi ile 'Deniz Gezmiş bana gazoz ısmarlamıştı' demesi arasında hiçbir fark yok. Cıvık, iğrenç insasların, çağrışımların tek amacı Deniz Gezmiş ismi üzerinden reklam yapmak. Vıcık vıcık ve mide bulandıran bir istismar söz konusu bu gündemin içinde.

diye devam etmektedir.

Taha Akyol da Hürriyet gazetesindeki 7 Mayıs ve 9 Mayıs 2012 tarihli köşe yazılarında

Genç yaşta asılmaları elbette kamu vicdanını kanatmıştır. Fakat Che ve Deniz'in resimlerinin yanına bir de kalpaklı Mustafa Kemal resmi koyarak bir kesimde yaratılan efsanenin hiçbir gerçekliği yoktur. Gezmiş ve arkadaşlarının kırk yıl öncesinin dünyasında kapıldıkları 'şehir gerillası' romantizmini yeni nesillere idealize ederek sunmak yanlıştır" ve "Bugün belli bir kesimde Che efsanesi gibi bir Deniz Gezmiş efsanesi var, romantize ediliyor. Halbuki sağ için de sol için de 'dava uğruna ölmek' tutkusundan sakınmak gerekir. Deniz'in 'niyet'i idealize edilirken, seçtiği silahlı eylem yolunun yanlış olduğu yeni nesillere anlatımalıdır.

şeklindeki sözleri ile efsaneleştirmenin hata olduğunu söylemektedir.

Atilla Yayla (Zaman/08.05.2012) ise köşesinden

Bu isimler etrafında, samimi ve içten acıları çevreleyip boğan efsaneler oluşturuldu; cinayetler yalan ve yanlış birçok şeyi yeni nesillere benimsettirmek için araçsallaştırıldı. Artık 'darağacında üç yiğit' efsanesi etrafındaki ajitasyon ve kara propagandanın tartışılması lazım.

diye seslenmektedir.

Haberlerde hatıralar ile fantezilerin birbirine karıştığı bir süreç de işletilmektedir. Örneğin, 07.05.2012 tarihli Cumhuriyet gazetesinde, "Ankaralılar Deniz'lerin 40 yıl önce idam edildikleri saati, onların infaz edilirken ısıkla çaldıkları 'Rodrigo'nun Gitar Konçertosu'nu ${ }^{5}$ dinleyerek beklediler" şeklindeki haber kurmacaya dayanmaktadır. Erdal Öz'ün Gülünün Solduğu Akşam (1987) adlı kitabında bulunan notlara göre, Gezmiş idamının bir bardak demli çay içtikten sonra bu parçayı dinleyerek olacağını hayal etmiştir. Gezmiş ve arkadaşlarının idam edilmeden önce son istekleri üzerine farklı iddialar bulunmakla beraber idam anında orada bulunan Halit Çelenk, çeşitli gazetelere verdiği röportajlarda böyle bir istekten hiç bahsetmemektedir. Çelenk, Evrensel gazetesindeki röportajında (07.05.2012) önce Deniz Gezmiş'in, daha sonra

5 Rodrigo'nun Gitar Konçertosu olarak da bilinen Concierto de Aranjuez, klasik müzik bestecisi ve piyano virtüözü Joaquin Rodrigo Vidre'nin İspanya iç savaşı sırasında Franco diktatörlüğünün halka çektirdiği acı ve zulmü anlattığı eseridir. 
onun idamı izletilen Yusuf Aslan'ın ve son olarak da aynı şekilde Aslan'ın idamı izletilen Hüseyin İnan'ın asıldığını anlatmaktadır. Aynı anda asıımadıkları gibi infazları sırasında ıslıkla parçayı çalmaları da sözkonusu olmamıştır.

\section{Algısal İmge}

Algısal imgede duyusal öğeler ve dış görünüşe dair özellikler öne çıkmaktadır. 16 Temmuz 1971'de başlayan THKO-1 Davası ile ilgili haberlerde "Gezmiş önde, 13 kişilik grup salona girdi. Salonda sol yumrukları havada görüldü. Hepsi spor kıyafetliydi" (Cumhuriyet/17.07.1971) şeklinde tasvir edilmektedir.

Cengiz Çandar "68 Kuşağı” adlı yazısında (Hürriyet/07.05.2002) “Türkiye'de 1968'de, Fransa'dan gelen ilk dalganın etkisiyle patlak veren öğrenci hareketi, Deniz Gezmiş'in, 1.91 'lik boyunda ve tepeden tırnağa idealist olduğu belli kişiliğinde 'simgesi'ni buldu" sözleri ile İlhan Selçuk "Üç Fidan” adlı yazısında (Cumhuriyet/07.05.2002) da "Uzun boylu, dal gibi, fidan gibi bir genç" diye tasvir etmektedir.

Kişilik özellikleri ise Evrensel (06.05.2002) gazetesinde Mustafa Yalçıner'den aktarılan "Deniz'in en temel özelliği baştan aşağı coşku oluşuydu, dizginsiz bir heyecan oluşuydu, sürekli eylem halinde oluşuydu, duyarlılığıydı" sözleri ile tasvir edilmektedir. Yine Evrensel (06.05.2012) gazetesinde İhsan Çaralan da kişilik özelliklerini "Onları, daha ileri bir mevziden anmak!" başlıklı yazısında "Deniz, Hüseyin ve Yusuf'un kişilikleri, ataklıkları, fedakarlıkları, davalarını yaşam pahasında savunmada gösterdikleri kararlııkları, baş eğmez devrimci tutumları ve halka bağlılıkta gösterdikleri sadakat konularında hiçbir tartışma yoktur." sözleriyle, Atilla Yayla (Zaman/08.05.2012) ise "Heyecanı aklının önüne geçen gençlerdi" sözleriyle anlatmaktadır.

\section{Grafik Imge}

Mitleştirmenin grafik imgesinin bir dalı olarak fotoğraflar, hatıralarla birlikte ikonun hafızlarda canlı tutulmasına katkıda bulunur. Deniz Gezmiş'in ve arkadaşlarının idamıyla ilgili haberlerde kullanılan fotoğrafları gençlerin kendi fotoğrafları ile anma törenlerinde çekilenler olarak iki ana gruba ayırabiliriz. Gezmiş'in kendi fotoğrafları arasında sık kullanılan iki kare dikkat çekmektedir; bunlardan biri sol yumruğu havada, öğrencilere karşı konuşurken görüldüğü kare ile yıllar içinde birçok haberde kullanılan yeşil parkalı fotoğrafıdır ${ }^{6}$. İkinci fotoğraf; Cumhuriyet (07.05.2002/6.sayfa), Cumhuriyet (06.05.2012/4.sayfa), Evrensel (06.05.2002/1.sayfa), Evrensel (07.05.2002/3.sayfa), Evrensel (07.05.2012/2.sayfa), Hürriyet (06.05.2012/2.sayfa), Milliyet (06.05.2002/2. sayfa) ve Sabah (07.05.2012/20.sayfa) gazetelerindeki haberlerde kullanılmıştır.

Cumhuriyet gazetesinin ilk sayfasında yer alan 6 Mayıs 1992 ve 6 Mayıs 2012 tarihlerindeki iki haberde de Deniz Gezmiş önde olacak şekilde Yusuf Aslan ve Hüseyin İnan'ın sadece yüzleri, bir bulut üzerinden yeryüzünü izlermiş gibi yukarıdan aşağıya bakar şekilde kullanılmıştır.

6 "Yeşil parka"lı sembol fotoğrafı çeken ve Gezmiş'in arkadaşı olan Ergin Konuksever ile yapılan röportaja dayandırılan haberde fotoğrafın Gezmiş'in yakalanarak Ankara'ya getirildiği gün olan 17 Mart 1971'de cezaevine götürülürken çekildiği ifade edilmektedir (www.cumhuriyet.com.tr/haber/diger/59832/Ben_kimseye_ kiyamadim_.html). 
İdamların yıldönümlerindeki haberlerde kullanılan diğer fotoğraflar ise Ankara Karşıyaka Mezarlığı'ndaki mezarları başındaki törenlerde aile üyeleri ya da politikacılara dair kareler ile üzerinde Gezmiş ve arkadaşlarının resimleri bulunan pankartlar taşıyan grupların fotoğraflarıdır.

Çağdaş Söylenler'de mitin nasıl algılandığını Fransız bayrağına selam veren zenci bir askerin resmi üzerinden değerlendiren Roland Barthes (2011:195) asker ve fotoğrafik imajın birlikte düz anlamsal göstergeyi oluşturduğunu söyler. Bu fotoğrafın yan anlamın göstereni olarak yeni bir gösterene dönüşerek sömürgecilik, milliyetçilik gibi ideolojik çağrışımlara nasıl kapı araladığını tartışır. Bu noktadan bakıldığında 7 Mayıs 1992 tarihli Sabah gazetesinin 13. sayfasında "Deniz Gezmiş orak çekiçli bayrakla anıldı" başlıklı haberin yanında verilen fotoğrafta Gezmiş'in mezarı başında sol yumrukları havada bir grup görülmektedir. Fotoğraf, haber metnini tamamlayacak şekilde sol, komünist devrim ve 1980 öncesindeki çatışmalara dair olumsuz bir göndermede bulunmaktadır.

Aralarında Gezmiş ve arkadaşlarının resimli pankartlarını taşıyan kişilerin bulunduğu kalabalık grupların fotoğraflarının altında "Hepimiz birer Deniz'iz (Cumhuriyet/06.05.2002)", “Deniz’ler ölmedi. Devrim şehitleri ölümsüzdür (Cumhuriyet/06.05.2002)", "Mezarı başında mücadeleye devam sözü (Evrensel/07.05.2002)", "40 yıldır emekçilerin mücadelesinde yaşıyorlar (Evrensel/06.05.2012)", "Şimdi Deniz olmalı (Hürriyet/06.05.2012)" gibi resim altı yazılarına yer verilmektedir. Bu fotoğraflar ise sol, komünist devrim ve mücadele kavramlarına olumlu bir göndermede bulunmaktadır.

\section{Sonuç Yerine}

Modern zamanların mitik kahramanlaştırmalarında medyanın oynadığı rolü Deniz Gezmiş örneğinden hareketle anlamaya gayret eden bu çalışma, gazetelerdeki haber ve köşe yazıları üzerinden mitleştirmenin karakterini ortaya koymaya yöneliktir.

Haberlerde adı ilk kez 1968 yılında geçen Gezmiş, ülkemizde öğrenci lideri dendiğinde ilk akla gelen isimdir. Eylemleri ve dramatik idamıyla hatırlanan ve medya sayesinde popüler kültür ikonuna dönüştürülen Gezmiş'in medyatik mitleştirilmesi 1990'lardan itibaren artmış görünmektedir. Gezmiş ve arkadaşlarının hatıraları, fotoğrafları ve eşyaları üzerinde inşa edilen yarı gerçek yarı kurmaca kahramanlık hikayeleri, üzerine sıkılan magazin sosuyla daha ilgi çekici, daha okunur hale getirilmeye çalışılmaktadır. Medyatik bir mit olarak Gezmiş; fanteziler ile harmanlanmış dramatik hatıralar, canlı ve akılda kalıcı tasvirler, neredeyse gerçeğin yerine geçen metaforik söylemlere başvurulan ikonik bir yeni gerçeklik inşası olarak işleyen sürecin bir parçası olarak görülebilir.

İdamlara yönelik bakış açısında gazeteler arasındaki farka bakıldığında merkez ve sol yönelimli gazetelerdeki haber ve köşe yazılarının sadece bir tanesinde (Taha Akyol/ Hürriyet) olumsuz bir dil kullanıldığı dikkati çekerken Gezmiş ve arkadaşlarından olumsuz/suçlayıcı bir dille söz edilen 8 haber ile 4 köşe yazısı da sağ yönelimli gazetelerde yayımlanmıştır. Ancak, dikkat çekici husus, sağ yönelimli gazetelerdeki 4 haber ve 3 köşe yazısında mitleştirmeye katkıda bulunan oldukça olumlu bir dil kullanılmış olmasıdır. Özellikle, 1990 sonrası dönemde idamların haksızlığının büyük 
oranda kabul edildiği görülmektedir. Bu durumda tarihsel ve toplumsal atmosferdeki değişimin etkili olduğu sonucuna ulaşmak mümkündür.

Geniş bir zaman dilimini kapsadığı için örneklemin belirlenen tarihlerle sınırlandırılı̆̆ı bu çalıșmada, araștırma mecrası olarak yazılı basın tercih edilmiştir. Yazılı basındaki haberlerin bellekte tutulması genellikle televizyon haberlerinin bellekte tutulmasından daha kolay ve uzun sürelidir ve nitelik olarak da televizyon haberlerinden daha yüksek olduğu düşünülür (Robinson ve Levy, 1996:23). Bu durum, yazılı basındaki haberlerin ikna edici etkisini ve bundan dolayı gücünü zenginleştirebilir. Çalışmada, görsel medya yerine, yazılı basının yani günlük gazetelerin incelenmesinin sebeplerinden biri de budur. Görsel medya, yani televizyonun, tercih edilmemesinin diğer sebebi ise ülkemizde televizyon yayınlarının ancak 1960'lı yıllarda başlamış olması ve 1990'lara kadar devlet tekelinde kalmış olmasıdır. Ancak, araştırmanın televizyon başta olmak üzere diğer kitle iletişim mecralarına genişletilmesi hem karşılaştırma için yeni imkanlar sağlayacak hem de ufuk açıcı olacaktır. Çeşitli ülkelerdeki öğrenci liderlerinin medya temsillerinin karşılaştırılması da ilginç sonuçlar ortaya çıkarabilir. Zira, hem basının gelişimi hem de öğrenci hareketlerinin seyri açısından ülkeler arasında kültürel, tarihsel, sosyal, politik, ekonomik ve konjonktürel farklar bulunmaktadır. Bu farkların haberlere ve liderlerin medyadaki sunumlarına etkide bulunup bulunmadığı, bulunduysa nasıl ve hangi yönde olduğu ortaya konularak karşılaştırma yapılabilir.

\section{Kaynakça}

Adaklı, Gülseren (2001). "Popüler ikon olarak sermayedar: Sakıp Sabancı." Praksis. 4(1):242255.

Akyol, Taha (2012a). "Deniz Gezmiş efsanesi." Hürriyet. 09.05.2012.

Akyol, Taha (2012b). “Deniz Gezmiş’in idam oylamasına Türkeş katılmadı.” Hürriyet. 07.05.2012.

Aysan, Yılmaz. (2013). Afişe Çıkmak 1963-1980 Solun Görsel Serüveni. İstanbul: İletişim.

Bâkiler, Yavuz Bülent (2002). "Hem komünist hem de Atatürkçü olunmaz." Türkiye. 07.05.2002.

Barthes, Roland (1998). Anlatıların Yapısal Çözümlemelerine Giriş. Çev. Mehmet Rıfat, Sema RIfat. İstanbul: Gerçek.

Barthes, Roland (2011). Çağdaş Söylenler (Mythologies). Çev. Tahsin Yücel. İstanbul: Metis.

Burnett, Ron (2012). İmgeler Nasıl Düşünür? Çev. Güçsal Pusar. İstanbul: Metis.

Coward, Rosalin ve Ellis, John (1985). Dil ve Maddecilik. Çev. Esen Tarım. İstanbul: Iletişim.

Çandar, Cengiz (2002). "68 Kuşağı." Hürriyet. 07.05.2002.

Çaralan, İhsan (2012). “Onları, daha ileri bir mevziden anmak!" Evrensel. 06.05.2012.

Debord, Guy (2006). Gösteri Toplumu. Çev. Aysen Ekmekçi, Oksan Taşkent. İstanbul: Ayrıntı.

Dündar, Can (2002). "O adam neden sadece 3 fotoğraf çekti?” Milliyet. 07.05.2002. 
Eliade, Mircea (2001). Mitlerin Özellikleri. Çev. Sema Rıfat. İstanbul: Om Kuram.

Ellis, John ve Coward, Rosalind (1985). Dil ve Maddecilik. Çev. Emrah Tarım, Ankara: Iletişim.

Er, Rahim (2012). “Onlar hain mi, kahraman mı?” Türkiye. 08.05.2012.

Feyizoğlu, Turan (2004). Deniz: Bir İsyancının İzleri. İstanbul: Ozan Yayınları.

Fiske, John (1996). İletişim Çalışmalarına Giriş. Çev. Süleyman İrvan. Ankara: Ark.

Fiske, John (1996). İletişim Çalışmalarına Giriş. Çev. Süleyman İrvan). Ankara: Bilim ve Sanat Yayınları.

Foss, Susan (2004). Rhetorical Criticism: Exploration \& Practice. Illinois: Waveland Press.

Foster, Hal (2008). "Kültürel Direniş." Sanat/Siyaset: Kültür Çağında Sanat ve Kültürel Politika. Ali Artun (der.) içinde. İstanbul: İletişim. 129-193.

Fremon, Yves (2003). 3000 Yııın Ayaklanmaları. Çev. Ali Çakıroğlu. İstanbul: Aykırı.

Friedman, Norman (2004). "İmge”, Kitap-lık, Aylık Edebiyat Dergisi, Çev. Kemal Atakay, Temmuz, Sayı: $74: 75-90$.

Giddens, Anthony (2005). Ulus-Devlet ve Şiddet. Çev. Cumhur Atay. İstanbul: Devin.

Gitlin, Todd (1980). The whole world is watching: Mass media in the making\&unmaking of the new left. California: University of California Press.

Heywood, Andrew (2007). Siyasi İdeolojiler. Ankara: Adres.

Honko, Lauri (1984). "The Problem of Defining Myth." Sacred Narrative: Readings in the Theory of Myth. Alan Dundes (der.) içinde. Berkeley: University of California Press.

Hooke, Samuel (1963). Middle Eastern Mythology. Harmondsworth: Penguin Books.

Ilıcak, Nazlı (1982). “Tarihten bir yaprak.” Tercüman. 07.05.1982.

llıcak, Nazlı (2012). “6 Mayıs ve idamlar.” Sabah. 07.05.2012.

İnal, Ayşe (2003). "Roland Barthes:Bir Avant-Garde Yazarı." Iletişim. 1(1): 9-38.

Kellner, Douglas (2011). "Barack Obama ve Ünlü Gösterisi.” Seçim Kampanyalarında Geleneksel Medya, İnternet ve Sosyal Medyanın Kullanımı. Yusuf Devran (der.) içinde. Çev. Leyla Keskiner. İstanbul: Başlık Yay. 45-83.

Kniazeva, Maria and Belk, Rusell W. (2010). "Supermarkets as libraries of postmodern mythology." Journal of Business Research. 3(7): 748-753.

Lévi-Strauss, Claude (2013). Mit ve Anlam. Çev. Yavuz Demir. İstanbul: İthaki. 
March, Jenny (2014). Klasik Mitler. Çev. Semih Lim. İstanbul: İletişim.

Mitchell, William T. (2005). İkonoloji. Çev. Hüsamettin Arslan. İstanbul: Paradigma.

Mumcu, Uğur (1982). "Sesleniş" Cumhuriyet. 07.05.1982.

Öz, Erdal (1987). Gülünün Solduğu Akşam. İstanbul: Can.

Pierce, Charles S. (1958). "The Icon, Index, and Symbol." Collected Papers. Charles Hartshorne and Paul Weiss (der.) içinde. Cambridge University Press.

Piercy, Joseph (2014). Semboller: Everensel Bir Dil. İstanbul: Aykırı Araştırma.

Robinson, John and Levy, Mark (1996). "News media use and the informed public: A 1990s update."Journal of Communication. 46(2): 129-135.

Selçuk, İlhan (1992). "20 Yıl Sonra.” Cumhuriyet. 06.05.1992.

Selçuk, İlhan (2002). “Üç Fidan.” Cumhuriyet. 07.05.2002.

Tamer, Rauf (1972). “idam yetmez, kök kazımalı.” Tercüman. 07.05.1972.

Temelkuran, Ece (2002). "Siz de bir dilim Deniz Gezmiş alır mıydınız?" Milliyet. 06.05.2002.

Türköne Mümtaz’er (2012). “Deniz Gezmiş'in hatırası.” Zaman. 06.05.2012.

Yalçıner, Mustafa (2012). "Denizler ve Halkın Kurtuluşu." Evrensel. 07.05.2012.

Yayla, Atilla (2012). "Deniz Gezmiş'in haksız idamı ideolojik idealini meşrulaştırır mı?” Zaman. 08.05.2012.

Zizek, Slavoj (2002). İdeolojinin Yüce Nesnesi. Çev. Tuncay Birkan. İstanbul: Metis. 